\title{
Enterobacter turicensis sp. nov. and Enterobacter helveticus sp. nov., isolated from fruit powder
}

Correspondence

Roger Stephan

stephanr@fsafety.unizh.ch

\author{
Roger Stephan, ${ }^{1}$ Stefanie Van Trappen, ${ }^{2}$ Ilse Cleenwerck, ${ }^{2}$ \\ Marc Vancanneyt, ${ }^{2}$ Paul De Vos $^{2}$ and Angelika Lehner ${ }^{1}$ \\ ${ }^{1}$ Institute for Food Safety and Hygiene, Vetsuisse Faculty University of Zurich, \\ Winterthurerstrasse 272, 8057 Zurich, Switzerland
}
${ }^{2}$ BCCM/LMG Bacteria Collection, Laboratorium voor Microbiologie, Universiteit Gent, K.L. Ledeganckstraat 35, 9000 Gent, Belgium

\begin{abstract}
Four Gram-negative, facultatively anaerobic, non-spore-forming isolates of coccoid rods were obtained from fruit powder and investigated in a polyphasic taxonomic study. Comparative 16S rRNA gene sequence analysis allocated the isolates to the family Enterobacteriaceae. Their phylogenetic position within the family Enterobacteriaceae was confirmed by $r p o B$ sequence analysis and as the highest $r p o B$ sequence similarities were obtained with Enterobacter radicincitans, Enterobacter cowanii and Enterobacter sakazakii, the isolates clearly belong to the genus Enterobacter. Biochemical data revealed that the isolates can be separated into two distinct groups that represent two novel species, as confirmed by DNA-DNA hybridizations. The two novel species can be differentiated from their nearest neighbours by the following characteristics: the utilization of sucrose, D-sorbitol, putrescine and mucate, the hydrolysis of aesculin and a negative result in the Voges-Proskauer reaction. It is therefore proposed that these novel isolates are classified as Enterobacter turicensis sp. nov. (type strain $508 / 05^{\top}=\mathrm{LMG}$ $23730^{\top}=\mathrm{DSM} 18397^{\top}$ ) and Enterobacter helveticus sp. nov. (type strain $513 / 05^{\top}=\mathrm{LMG}$ $\left.23732^{\top}=\operatorname{DSM} 18396^{\top}\right)$.
\end{abstract}

The current US Food and Drug Administration method for the detection of Enterobacter sakazakii includes a preenrichment procedure in buffered peptone water (BPW), enrichment in Enterobacteriaceae enrichment (EE) broth, plating on violet red bile glucose agar (VRBG) and the picking of five grown colonies onto tryptone soy agar (TSA) plates, which are incubated at $25^{\circ} \mathrm{C}$ for $48-72 \mathrm{~h}$. Yellowpigmented presumptive colonies have to be further identified. Based on $\alpha$-glucosidase activity, another biochemical property of E. sakazakii, several differential media have been developed recently (Iversen et al., 2004; Oh \& Kang, 2004). Two of these media, Oxoid chromogenic Enterobacter sakazakii agar (Oxoid CM1055; Oxoid), also known as the Druggan-Forsythe-Iversen (DFI) formulation (Iversen et al., 2004), and Enterobacter sakazakii isolation agar (ESIA; AES), are commercially available.

Abbreviations: BPW, buffered peptone water; DFI, Druggan-ForsytheIversen formulation; EE, Enterobacteriaceae enrichment; VRBG, violet red bile glucose.

The GenBank/EMBL/DDBJ accession numbers for the 16S rRNA and rpoB gene sequences of strains $508 / 05^{\top}, 610 / 05,513 / 05^{\top}$ and $1159 / 04$ are DQ273681, DQ273680, DQ273688 and DQ273683 and DQ779998, DQ780000, DQ779997 and DQ779999, respectively.
In a recent study, a set of 12 strains isolated from fruit powder showed yellow-pigmented presumptive E. sakazakii colonies on TSA plates as well as typical turquoise colonies on DFI medium when incubated at the recommended temperature (Lehner et al., 2006). API 32E analysis of these strains revealed ambiguous results, but none of the strains were clearly identified as E. sakazakii. The API 32E tests suggested identifications as Escherichia vulneris, Pantoea spp. and Buttiauxiella agrestis (previously known as Citrobacter group F) for several of the strains, but with low levels of confidence. In order to obtain more information on the exact taxonomic position of these fruit powder isolates, $16 \mathrm{~S}$ rRNA gene sequencing was performed (Lehner et al., 2006). Comparative analysis revealed that all of the isolates were clearly distinct from E. sakazakii with gene sequence similarities <97\% (Lehner et al., 2004).

Four of these strains were further characterized and, based on the results of a polyphasic taxonomic study, it can be concluded that these isolates represent two novel species of the genus Enterobacter.

Fruit powder (150 g) samples (spray-dried powder of $100 \%$ fruit pulp or vacuum-dried granules of fruit juice) were enriched in a first step for $24 \mathrm{~h}$ at $37^{\circ} \mathrm{C}$ in $1.5 \mathrm{l} \mathrm{BPW}$. In a second step, $0.1 \mathrm{ml}$ of BPW was subcultured in $9 \mathrm{ml} \mathrm{EE}$ 
broth and incubated for a further $24 \mathrm{~h}$ at $37^{\circ} \mathrm{C}$. This second enrichment was then plated on VRBG agar and on Oxoid chromogenic E. sakazakii agar. After incubation for $24 \mathrm{~h}$ at $37^{\circ} \mathrm{C}$, isolates $508 / 05^{\mathrm{T}}\left(=\mathrm{LMG} 23730^{\mathrm{T}}=\mathrm{DSM} 18397^{\mathrm{T}}\right)$, $610 / 05$ (=LMG 23731), 513/05 $\left(=\right.$ LMG $23732^{\mathrm{T}}=\mathrm{DSM}$ $\left.18396^{\mathrm{T}}\right)$ and $1159 / 04$ ( $=$ LMG 23733) were recovered as typical turquoise colonies from E. sakazakii agar as well as yellow-pigmented colonies on TSA plates.

For morphological and physiological studies, strains were grown on BHI medium. Physiological studies were performed by using API 32E and Biotype 100 tests (bioMérieux) with Biotype Medium 1, according to the manufacturer's instructions. Tests for motility and indole and $\mathrm{H}_{2} \mathrm{~S}$ production were performed in SIM agar (BD Diagnostics) at $37^{\circ} \mathrm{C}$.

The four isolates from fruit powder consisted of facultatively anaerobic, motile, Gram-negative coccoid rods $(1.0 \times 1.5$ $2.5 \mu \mathrm{m})$. After $24 \mathrm{~h}$ aerobic incubation at $37^{\circ} \mathrm{C}$ on sheep blood agar, colonies were non-haemolytic and yellowpigmented. Yellow pigmentation increased when colonies were exposed to light. All strains were catalase-positive and weakly oxidase-positive. The strains could grow at temperatures of 10 to $44^{\circ} \mathrm{C}$. The minimal $\mathrm{pH}$ for growth at $37^{\circ} \mathrm{C}$ was $\mathrm{pH} 5.0$ for all strains.

The four strains could be separated into two groups on the basis of biochemical patterns and could be differentiated by the following characteristics: strains $508 / 05^{\mathrm{T}}$ and $610 / 05$ were positive for L-ornithine decarboxylase and for the fermentation of L-rhamnose, but were negative in tests for 5-bromo-3-indoxyl-nonanoate utilization. In contrast, strains $513 / 05^{\mathrm{T}}$ and $1159 / 04$ were positive for 5-bromo-3indoxyl-nonanoate utilization, but negative in tests for L-ornithine decarboxylase and for the fermentation of L-rhamnose. Moreover, in contrast to strains $508 / 05^{\mathrm{T}}$ and $610 / 05$, strains $513 / 05^{\mathrm{T}}$ and $1159 / 04$ could utilize the following substrates: trans-aconitate, 5-keto-D-gluconate, protocatechuate, $p$-hydroxybenzoate, quinate, putrescine and DL- $\alpha$-amino-n-butyrate.

Sequencing of the 16S rRNA genes was performed according to Lehner et al. (2006). The almost complete $16 \mathrm{~S}$ rRNA gene sequences comprising $1266\left(508 / 05^{\mathrm{T}}\right), 1319(610 / 05), 1245$ $\left(513 / 05^{\mathrm{T}}\right)$ and $1267(1159 / 04)$ nucleotides were determined and aligned to 28000 almost full-length 16S rRNA gene sequences by using the alignment tool of the ARB program package (Ludwig et al., 2004). Alignments were refined by visual inspection. Analysis of the $16 \mathrm{~S}$ rRNA gene sequences was performed using the distance-matrix tool and a phylogenetic tree was estimated using the neighbour-joining method combined with a Felsenstein correction, all of which are included in the ARB package. The significance of branchings was evaluated by a bootstrap analysis of 1000 replicates. Phylogenetic analyses were performed using the distance matrix and the neighbour-joining dendrogram tool included in the ARB software package employing special data structures (PT-servers) derived from the ssu-rRNA database, 'ssu_jan04.arb'.

The $16 \mathrm{~S}$ rRNA gene sequences of strains $508 / 05^{\mathrm{T}}$ and $610 / 05$ showed $98.7 \%$ sequence similarity to each other and formed a separate branch in the phylogenetic tree (Fig. 1), although weakly supported by bootstrap analysis. They were grouped most closely with a cluster containing Erwinia mallotivora LMG $2708^{\mathrm{T}}$ with 95.7 and $94.9 \%$ similarity, Erwinia amylovora LMG $2024^{\mathrm{T}}$ with 96.6 and $95.8 \%$ similarity and Erwinia rhapontici DSM $4484^{\mathrm{T}}$ with 96.5 and $96.0 \%$ sequence similarity, respectively. High sequence similarities were also found to Enterobacter radicincitans CIP $108468^{\mathrm{T}}$ with 95.3 and $94.9 \%$ similarity and Enterobacter cowanii CIP $107300^{\mathrm{T}}$ with 96.7 and $96.4 \%$ gene sequence similarity, respectively.

The 16S rRNA gene sequences of strains $513 / 05^{\mathrm{T}}$ and 1159 / 04 showed $99.4 \%$ sequence similarity to each other and formed a separate branch in the phylogenetic tree (Fig. 1), although weakly supported by bootstrap analysis. They were grouped most closely to a cluster containing Enterobacter sakazakii DSM $4485^{\mathrm{T}}$ (AB004746) with 96.5 and $96.4 \%$ gene sequence similarity and Enterobacter sakazakii ATCC 51329 (AY752937) with 96.9 and $96.8 \%$ similarity, respectively. High gene sequence similarities were also found to Escherichia coli ATCC $11775^{\mathrm{T}}$ (X80725) and Shigella flexneri ATCC $29903^{\mathrm{T}}$ (X96963) with $96.1 \%$ and $96.3 \%$ similarity, respectively. The 16S rRNA gene sequence similarities between strains $508 / 05^{\mathrm{T}}$ and $610 / 05$ and $513 / 05^{\mathrm{T}}$ and $1159 / 04$ varied between 95.7 and $96.2 \%$. Overall, no 16S rRNA gene sequence similarities above $97 \%$ were found with any recognized species, suggesting that the strains represent novel species (Stackebrandt \& Goebel, 1994).

Since the branches representing the different genera of the family Enterobacteriaceae are not monophyletic and not supported by high bootstrap values and since the highest similarity values with the fruit powder strains are found with reference strains of different genera, it can be concluded that for the family Enterobacteriaceae, the similarity levels obtained reflect a high level of homoplasy in the $16 \mathrm{~S}$ rRNA gene sequences.

$16 \mathrm{~S}$ rRNA gene sequence analysis indicates that the strains belong to the family Enterobacteriaceae but based on these results alone, the novel strains cannot be allocated unequivocally to a narrower taxonomic level. As the usefulness of $r p o B$ sequence analysis for species discrimination within the family Enterobacteriaceae has been reported previously by several authors (Mollet et al., 1997; Drancourt et al., 2001; Li et al., 2004; Kämpfer et al., 2005), rpoB sequence analysis was performed with the four novel strains. Total DNA was prepared according to the protocol of Niemann et al. (1997). The $r p o B$ gene was amplified and sequenced following the protocol of Mollet et al. (1997). Sequence assembly was performed by using the AutoAssembler program (Applied Biosystems). Phylogenetic analysis was performed using TREECON software (Van de Peer \& De 


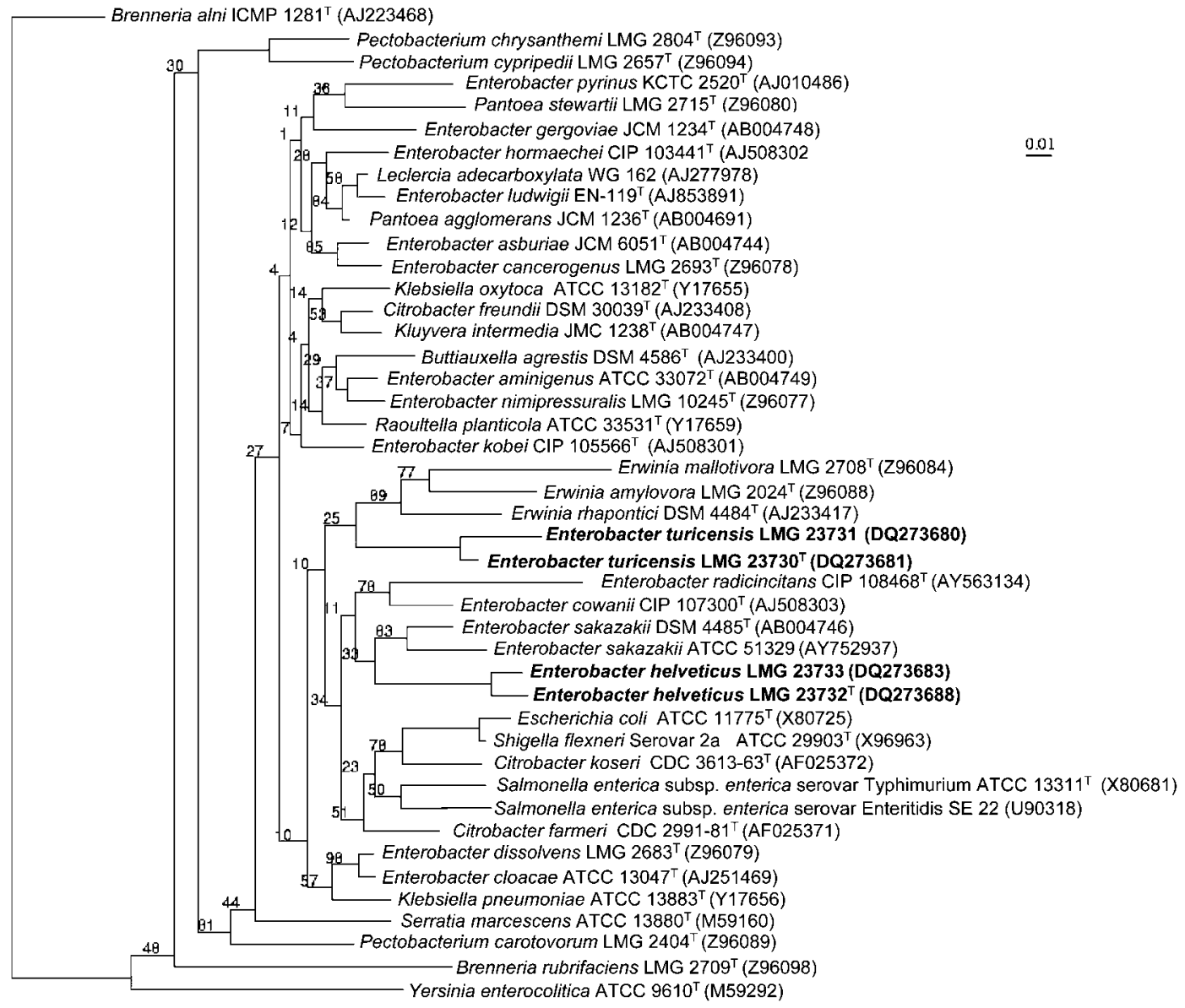

Fig. 1. Neighbour-joining dendrogram of $16 \mathrm{~S}$ rRNA gene sequences showing the estimated phylogenetic relationships between Enterobacter turicensis sp. nov., Enterobacter helveticus sp. nov. and related genera within the family Enterobacteriaceae. Bootstrap values (percentages of 1000 replicates) are shown. Bar, $0.01 \%$ nucleotide substitutions.

Wachter 1994) after including the consensus sequence in an alignment (CLUSTAL W, Thompson et al., 1994) of rpoB sequences collected from EMBL. Evolutionary distances were calculated using the Jukes \& Cantor evolutionary model and the resulting tree was constructed using the neighbour-joining method. Bootstrap values (500 replicates) were also calculated.

The $r p o B$ sequences of strains $508 / 05^{\mathrm{T}}$ and $610 / 05$ were identical. The highest $r p o B$ sequence similarities were found with Enterobacter radicincitans CIP $108468^{\mathrm{T}} \quad(91.9 \%$ similarity), Enterobacter cowanii CIP $107300^{\mathrm{T}}(90.2 \%)$ and Enterobacter sakazakii LMG $5740^{\mathrm{T}}(89.6 \%)$. The rpoB sequences of strains $513 / 05^{\mathrm{T}}$ and $1159 / 04$ were also identical and the highest sequence similarities to these strains were with those of Enterobacter sakazakii LMG $5740^{\mathrm{T}}$ (91.0\%), Enterobacter radicincitans CIP $108468^{\mathrm{T}}(90.8 \%)$, Enterobacter gergoviae ATCC $33028^{\mathrm{T}}(90.0 \%)$ and Enterobacter cowanii CIP $107300^{\mathrm{T}}(89.8 \%)$. The rpoB sequence similarity between strains $508 / 05^{\mathrm{T}}$ and $610 / 05$ and strains $513 / 05^{\mathrm{T}}$ and $1159 / 04$ was $91.6 \%$. The phylogenetic branch formed by $E$. sakazakii, E. radicincitans, E. cowanii and the novel strains is supported by a high bootstrap value (86\%) (Fig. 2), demonstrating that they clearly belong to the genus Enterobacter, taking into account that when using only one protein-coding gene, a possible genetic transfer cannot be excluded. Moreover, the similarity values found with their nearest neighbours are rather low (89.6-91.0\%) compared with the intraspecies similarity range of 98-100\% found in the family Enterobacteriaceae (Mollet et al., 1997), confirming that the fruit powder strains represent novel species within this family.

Finally, to confirm whether these novel strains represent two independent genospecies within the genus Enterobacter, DNA-DNA hybridizations were performed. DNA was prepared according to a modification of the method of Wilson (1987) and hybridizations were carried out at $46^{\circ} \mathrm{C}$ according to a modification of the method described by Ezaki et al. (1989). The DNA-DNA relatedness percentages obtained were the means of a minimum of four hybridizations. Reciprocal reactions (i.e. $\mathrm{A} \times \mathrm{B}$ and $\mathrm{B} \times \mathrm{A}$ ) were performed and the variation between them was within the accepted limits of this method (Goris et al., 1998). 


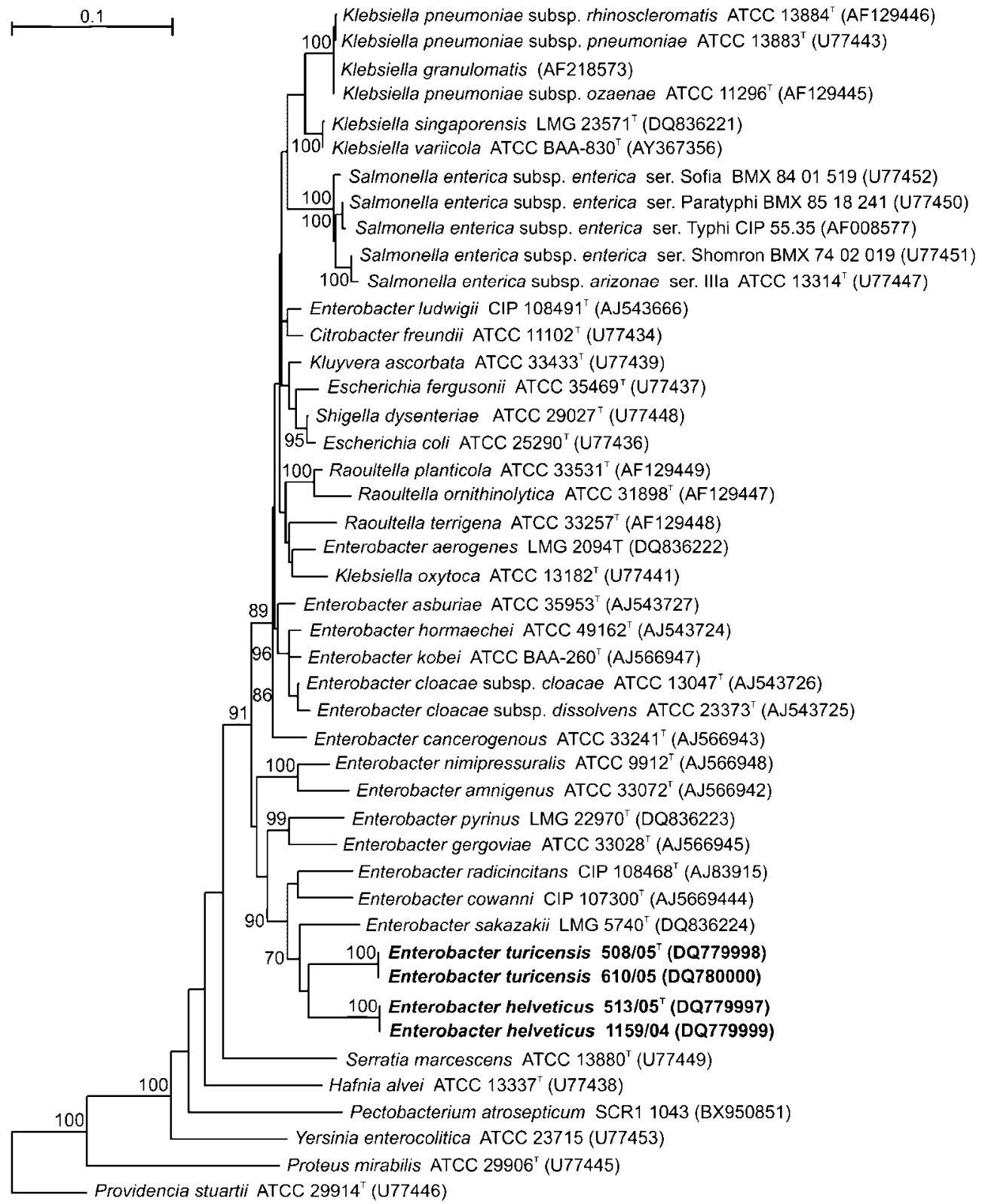

Fig. 2. Neighbour-joining dendrogram based on rpoB gene sequences of Enterobacter turicensis sp. nov., Enterobacter helveticus sp. nov. and related members of the family Enterobacteriaceae. Bootstrap values (percentages of 500 replicates) of $>70 \%$ are shown. Bar, $0.1 \%$ nucleotide substitutions.

The DNA-DNA hybridization results revealed that strains $508 / 05^{\mathrm{T}}$ and $610 / 05$ show a DNA-DNA relatedness of $95 \%$ while strains $513 / 05^{\mathrm{T}}$ and $1159 / 04$ show $100 \%$ DNA-DNA relatedness. The DNA-DNA relatedness between the strains of the different genospecies falls within a range of 23-27\%, which is clearly below $70 \%$, the generally accepted limit for species delineation (Wayne et al., 1987). On the basis of these genotypic results, it is clear that the four fruit powder strains represent two novel genomic species.

The overall DNA G + C content was determined from DNA prepared for the DNA-DNA hybridizations, according to the HPLC method (Mesbah et al., 1989). The values (means of three independent analyses of the same DNA sample) for strains $508 / 05^{\mathrm{T}}, 610 / 05,513 / 05^{\mathrm{T}}$ and $1159 / 04$ are $57.8,57.7$, 55.2 and $55.8 \mathrm{~mol} \%$, respectively. These values are consistent with the DNA G $+\mathrm{C}$ contents of other members of the genus Enterobacter (Richard, 1984; Inoue et al., 2000).

The results of this polyphasic analysis support the recognition of two novel Enterobacter species, for which the names Enterobacter turicensis sp. nov. and Enterobacter helveticus sp. nov. are proposed. Details of the physiological and biochemical characteristics of the two novel species are given 
Table 1. Phenotypic characteristics that differentiate Enterobacter turicensis sp. nov. and Enterobacter helveticus sp. nov. from related species of the genus Enterobacter

Strains: 1, Enterobacter turicensis sp. nov. $(\mathrm{n}=2) ; 2$, Enterobacter helveticus sp. nov. $(\mathrm{n}=2) ; 3$, Enterobacter sakazakii; 4, Enterobacter cowanii; 5, Enterobacter radicincitans; 6, Enterobacter gergoviae; 7, Enterobacter asburiae; 8, Enterobacter kobei; 9, Enterobacter cloacae subsp. cloacae; 10, Enterobacter cloacae subsp. dissolvens; 11, Enterobacter hormaechei; 12, Enterobacter cancerogenus; 13, Enterobacter nimipressuralis; 14, Enterobacter amnigenus biovar 1; 15, Enterobacter amnigenus biovar 2; 16, Enterobacter intermedius; 17, Enterobacter ludwigii; 18, Enterobacter pyrinus.,$- 0-10 \%$ positive; $-{ }^{+}, 10-20 \%$ positive; $\mathrm{V}, 20-80 \%$ positive; $+^{-}$, $80-90 \%$ positive;,+ 90-100 \% positive; ND, no data available. Data for other Enterobacter species are from Hoffmann et al. (2005) and Kämpfer et al. (2005).

\begin{tabular}{|c|c|c|c|c|c|c|c|c|c|c|c|c|c|c|c|c|c|c|}
\hline Characteristic & 1 & 2 & 3 & 4 & 5 & 6 & 7 & 8 & 9 & 10 & 11 & 12 & 13 & 14 & 15 & 16 & 17 & 18 \\
\hline Motility & + & + & + & + & + & + & $+^{-}$ & $+^{-}$ & + & + & $+^{-}$ & + & - & + & + & + & + & + \\
\hline \multicolumn{19}{|l|}{ Carbon source utilization: } \\
\hline$\alpha$-D-Melibiose & + & + & + & + & - & + & $+^{-}$ & + & + & + & $-{ }^{+}$ & - & + & + & + & + & + & + \\
\hline D-Sorbitol & - & - & - & + & + & - & $+^{-}$ & + & + & + & $-{ }^{+}$ & - & + & - & $\mathrm{ND}$ & + & + & - \\
\hline Putrescine & - & + & + & - & - & $\mathrm{V}$ & $-{ }^{+}$ & $\mathrm{V}$ & + & + & - & + & - & - & $\mathrm{ND}$ & - & - & + \\
\hline L-Fucose & - & - & - & - & ND & $\mathrm{V}$ & - & - & - & $\mathrm{V}$ & + & + & - & - & ND & $\mathrm{V}$ & $\mathrm{V}$ & - \\
\hline D-Arabitol & - & - & - & - & ND & + & - & - & - & - & $-^{+}$ & - & - & - & ND & - & - & + \\
\hline$\alpha$-L-Rhamnose & + & + & + & + & + & + & $+^{-}$ & + & + & + & + & + & + & + & $\mathrm{ND}$ & + & + & + \\
\hline
\end{tabular}

below. They can be clearly differentiated from their nearest neighbours by several properties including the utilization of sucrose, D-sorbitol, putrescine and mucate, the hydrolysis of aesculin and a negative result in the Voges-Proskauer reaction (see Table 1 ).

\section{Description of Enterobacter turicensis sp. nov.}

Enterobacter turicensis (tu.ri.cens' is. L. masc. adj. turicensis from Turicum/Zurich, from where the species was first isolated).

Cells are Gram-negative, coccoid rods that are facultatively anaerobic and motile. Cells are $1.0 \mu \mathrm{m}$ wide by $1.5-2.5 \mu \mathrm{m}$ long and occur singly or in pairs. After $24 \mathrm{~h}$ aerobic incubation at $37^{\circ} \mathrm{C}$ on TSA medium, colonies are yellowpigmented and convex. Catalase-positive and weakly oxidase-positive. Colonies grow well at $10{ }^{\circ} \mathrm{C}$ (within 3 days) but poorly at $44^{\circ} \mathrm{C}$. Positive for ornithine- and malonate decarboxylase reactions and negative for urease, arginine dihydrolase and lysine decarboxylase. Tests for indole and $\mathrm{H}_{2} \mathrm{~S}$ production and the Voges-Proskauer test are negative. Acid is produced from the following compounds: galacturonate, D-mannitol, D-maltose, D-glucose, L-arabinose, D-trehalose and L-rhamnose. No acid production is observed from L-arabitol, D-arabitol, 5-ketogluconate, phenol red, adonitol, palatinose, sucrose, inositol, $\mathrm{D}$-cellobiose or D-sorbitol. The chromogenic substrates ONPG, 4-nitrophenyl $\beta$-D-glucopyranoside, 4-nitrophenyl $\beta$-D-galactopyranoside, 4-nitrophenyl $\alpha$-D-glucopyranoside, 4-nitrophenyl $\alpha$-D-galactopyranoside and 4-nitrophenyl
$\alpha$-D-maltopyranoside are hydrolysed. The following compounds are not hydrolysed: 5-bromo-3-indoxyl-nonanoate, 4 -nitrophenyl $\beta$-D-glucuronide or L-aspartic acid 4-nitroanilide. Positive reaction in tests for the utilization of $\alpha$-Dglucose, $\beta$-D-fructose, D-galactose, D-trehalose, D-mannose, $\alpha$-D-melibiose, maltotriose, maltose, $\alpha$-lactose, $1-0$-methyl $\beta$-galactopyranoside, 1 -0-methyl $\alpha$-galactopyranoside, $\mathrm{D}$ cellobiose, $\beta$-gentiobiose, $1-0$-methyl $\beta$-D-glucopyranoside, aesculin, D-ribose, L-arabinose, D-xylose, $\alpha$-L-rhamnose, dulcitol, glycerol, D-mannitol, D-turanose, D-saccharate, mucate, L-malate, cis-aconitate, D-glucuronate, D-galacturonate, 2-keto-D-gluconate, $N$-acetyl-D-glucosamine, D-gluconate, DL-lactate, D-glucosamine, L-aspartate, L-glutamate, L-proline, L-alanine and L-serine. The following compounds are not utilized as sole sources of carbon: L-sorbose, sucrose, D-raffinose, lactulose, $\alpha$-L-fucose, D-arabitol, L-arabitol, xylitol, D-tagatose, myo-inositol, maltitol, D-sorbitol, adonitol, hydroxyquinoline- $\beta$-glucuronide, i-erythritol, 1-0-methyl $\alpha$-D-glucopyranoside, 3-0methyl D-glucopyranose, L-tartrate, D-tartrate, myo-tartrate, trans-aconitate, tricarballylate, 5-keto-D-gluconate, L-tryptophan, phenylacetate, protocatechuate, $p$-hydroxybenzoate, quinate, gentisate, $m$-hydroxybenzoate, benzoate, 3 -phenylpropionate, trigonelline, betain, putrescine, DL- $\alpha$ amino-n-butyrate, histamine, caprate, caprylate, L-histidine, fumarate, glutarate, DL-glycerate, DL- $\alpha$-amino-n-valerate, ethanolamine, tryptamine, itaconate, DL- $\beta$-hydroxybutyrate, malonate, propionate, L-tyrosine or 2-oxoglutarate. The DNA G + C contents of strains $508 / 05^{\mathrm{T}}$ and $610 / 05$ are 57.8 and $57.7 \mathrm{~mol} \%$, respectively. 
The type strain, strain $508 / 05^{\mathrm{T}}\left(=\mathrm{LMG} 23730^{\mathrm{T}}=\mathrm{DSM}\right.$ $\left.18397^{\mathrm{T}}\right)$, was isolated from fruit powder.

\section{Description of Enterobacter helveticus sp. nov.}

Enterobacter helveticus (hel.ve.ti' cus. L. masc. adj. helveticus from Helveticum/Switzerland, from where the species was first isolated).

Cells are Gram-negative, coccoid rods that are facultatively anaerobic and motile. Cells are $1.0 \mu \mathrm{m}$ wide by $1.5-2.5 \mu \mathrm{m}$ long and occur singly or in pairs. After $24 \mathrm{~h}$ aerobic incubation at $37^{\circ} \mathrm{C}$ on TSA medium, colonies are yellowpigmented and convex. Catalase-positive and weakly oxidase-positive. Colonies grow well at $44^{\circ} \mathrm{C}$, but poorly at $10{ }^{\circ} \mathrm{C}$. Positive in tests for the malonate decarboxylase reaction and negative in tests for urease, ornithine decarboxylase, arginine dihydrolase and lysine decarboxylase activities. Tests for indole and $\mathrm{H}_{2} \mathrm{~S}$ production and the Voges-Proskauer test are also negative. Acid is produced from the following compounds: galacturonate, D-mannitol, D-maltose, D-glucose, L-arabinose and D-trehalose. No acid production is observed for L-arabitol, L-rhamnose, 5-ketogluconate, phenol red, adonitol, palatinose, sucrose, D-arabitol, inositol, D-cellobiose or D-sorbitol. The chromogenic substrates ONPG, 5-bromo-3-indoxyl-nonanoate, 4 -nitrophenyl $\beta$-D-glucopyranoside, 4-nitrophenyl $\beta$-Dgalactopyranoside, 4-nitrophenyl $\alpha$-D-glucopyranoside, 4 -nitrophenyl $\alpha$-D-galactopyranoside and 4-nitrophenyl $\alpha$-D-maltopyranoside are hydrolysed. The following compounds are not hydrolysed: 4-nitrophenyl $\beta$-D-glucuronide and $\mathrm{L}$-aspartic acid 4-nitroanilide. Positive reaction in tests for the utilization of $\alpha$-D-glucose, $\beta$-D-fructose, D-galactose, D-trehalose, D-mannose, $\alpha$-D-melibiose, maltotriose, maltose, $\alpha$-lactose, 1-0-methyl $\beta$-galactopyranoside, 1-0-methyl $\alpha$-galactopyranoside, D-cellobiose, $\beta$-gentiobiose, $1-0$-methyl $\beta$-D-glucopyranoside, aesculin, D-ribose, L-arabinose, D-xylose, $\alpha$-L-rhamnose, dulcitol, glycerol, D-mannitol, D-turanose, D-saccharate, mucate, L-malate, cis-aconitate, trans-aconitate, D-glucuronate, D-galacturonate, 2-keto-Dgluconate, 5-keto-D-gluconate, $\mathrm{N}$-acetyl-D-glucosamine, D-gluconate, protocatechuate, $p$-hydroxybenzoate, quinate, putrescine, DL- $\alpha$-amino-n-butyrate, DL-lactate, D-glucosamine, L-aspartate, L-glutamate, L-proline, L-alanine and L-serine. The following compounds are not utilized as sole sources of carbon: L-sorbose, sucrose, D-raffinose, lactulose, $\alpha$-L-fucose, D-arabitol, L-arabitol, xylitol, D-tagatose, myoinositol, maltitol, D-sorbitol, adonitol, hydroxyquinoline- $\beta$ glucuronide, i-erythritol, 1-0-methyl $\alpha$-D-glucopyranoside, 3-0-methyl D-glucopyranose, L-tartrate, D-tartrate, myotartrate, tricarballylate, L-tryptophan, phenylacetate, gentisate, $m$-hydroxybenzoate, benzoate, 3-phenylpropionate, trigonelline, betain, histamine, caprate, caprylate, L-histidine, fumarate, glutarate, DL-glycerate, DL- $\alpha$-amino$\mathrm{n}$-valerate, ethanolamine, tryptamine, itaconate, DL- $\beta$ hydroxybutyrate, malonate, propionate, L-tyrosine or 2-oxoglutarate. The DNA G + C contents of strains 513/ $05^{\mathrm{T}}$ and $1159 / 04$ are 55.2 and $55.8 \mathrm{~mol} \%$, respectively.
The type strain, strain $513 / 05^{\mathrm{T}}\left(=\mathrm{LMG} 23732^{\mathrm{T}}=\mathrm{DSM}\right.$ $\left.18396^{\mathrm{T}}\right)$, was isolated from fruit powder.

\section{References}

Drancourt, M., Bollet, C., Carta, A. \& Rousselier, P. (2001). Phylogenetic analyses of Klebsiella species delineate Klebsiella and Raoultella gen. nov., with description of Raoultella ornithinolytica comb. nov., Raoultella terrigena comb. nov. and Raoultella planticola comb. nov. Int J Syst Evol Microbiol 51, 925-932.

Ezaki, T., Hashimoto, Y. \& Yabuuchi, E. (1989). Fluorometric deoxyribonucleic acid-deoxyribonucleic acid hybridization in microdilution wells as an alternative to membrane filter hybridization in which radioisotopes are used to determine genetic relatedness among bacterial strains. Int J Syst Bacteriol 39, 224-229.

Goris, J., Suzuki, K., De Vos, P., Nakase, T. \& Kersters, K. (1998). Evaluation of a microplate DNA-DNA hybridization method compared with the initial renaturation method. Can J Microbiol 44, 1148-1153.

Hoffmann, H., Stindl, S., Ludwig, W., Stumpf, A., Mehlen, A., Heesemann, J., Monget, D., Schleifer, K. H. \& Roggenkamp, A. (2005). Reassignment of Enterobacter dissolvens to Enterobacter cloacae as E. cloacae subspecies dissolvens comb. nov. and emended description of Enterobacter asburiae and Enterobacter kobei. Syst Appl Microbiol 28, 196-205.

Inoue, K., Sugiyama, K., Kosako, Y., Sakazaki, R. \& Yamai, S. (2000). Enterobacter cowanii sp. nov., a new species of the Enterobacteriaceae. Curr Microbiol 41, 417-420.

Iversen, C., Druggan, P. \& Forsythe, S. (2004). A selective medium for Enterobacter sakazakii, a preliminary study. Int J Food Microbiol 96, 133-139.

Kämpfer, P., Ruppel, S. \& Remus, R. (2005). Enterobacter radicincitans sp. nov., a plant growth promoting species of the family Enterobacteriaceae. Syst Appl Microbiol 28, 213-221.

Lehner, A., Tasara, T. \& Stephan, R. (2004). 16S rRNA gene based analysis of Enterobacter sakazakii strains from different sources and development of a PCR assay for identification. BMC Microbiol 4, 43.

Lehner, A., Nitzsche, S., Breeuwer, P., Diep, B., Thelen, K. \& Stephan, R. (2006). Comparison of two chromogenic media and evaluation of two molecular based identification systems for Enterobacter sakazakii detection. BMC Microbiol 6, 15.

Li, X., Zhang, D., Chen, F., Ma, J., Dong, Y. \& Zhang, L. (2004). Klebsiella singaporensis sp. nov., a novel isomaltulose-producing bacterium. Int J Syst Evol Microbiol 54, 2131-2136.

Ludwig, W., Strunk, O., Westram, R., Richter, L., Meier, H., Yadhukumar, R., Buchner, A., Lai, T., Steppi, S. \& other authors (2004). ARB: a software environment for sequence data. Nucleic Acids Res 32, 1363-1371.

Mesbah, M., Premachandran, U. \& Whitman, W. B. (1989). Precise measurement of the $\mathrm{G}+\mathrm{C}$ content of deoxyribonucleic acid by highperformance liquid chromatography. Int J Syst Bacteriol 39, 159-167.

Mollet, C., Drancourt, M. \& Raoult, D. (1997). rpoB sequence analysis as a novel basis for bacterial identification. Mol Microbiol 26, 10051011.

Niemann, S., Puhler, A., Tichy, H. V., Simon, R. \& Selbitschka, W. (1997). Evaluation of the resolving power of three different DNA fingerprinting methods to discriminate among isolates of a natural Rhizobium meliloti population. J Appl Microbiol 82, 477-484.

Oh, S. W. \& Kang, D. H. (2004). Fluorogenic selective and differential medium for isolation of Enterobacter sakazakii. Appl Environ Microbiol 70, 5692-5694. 
Richard, C. (1984). Genus VI. Enterobacter Hormaeche \& Edwards 1960 In Bergey's Manual of Systematic Bacteriology, vol. 1, pp. 465469. Edited by J. T. Staley, M. P. Bryant, N. Pfenning \& J. G. Holt. Baltimore: Williams \& Wilkins.

Stackebrandt, E. \& Goebel, B. M. (1994). Taxonomic note: a place for DNA-DNA reassociation and $16 \mathrm{~S}$ rRNA sequence analysis in the present species definition in bacteriology. Int J Syst Bacteriol 44, 846-849.

Thompson, J. D., Higgins, D. G. \& Gibson, T. J. (1994). CLUSTAL W: improving the sensitivity of progressive multiple sequence alignment through sequence weighting, position-specific gap penalties and weight matrix choice. Nucleic Acids Res 22, 4673-4680.

Van de Peer, A. \& De Wachter, R. (1994). TREECON for windows: a software package for the construction and drawing of evolutionary trees for the Microsoft Windows environment. Comput Appl Biosci 10, 569-570.

Wayne, L. G., Brenner, D. J., Colwell, R. R., Grimont, P. A. D., Kandler, O. K., Krichevsky, M. I., Moore, L. H., Moore, W. E. C., Murray, T. G. E. \& other authors (1987). International Committee on Systematic Bacteriology. Report of the ad hoc committee on reconciliation of approaches to bacterial systematics. Int $J$ Syst Bacteriol 37, 463-464.

Wilson, K. (1987). Preparation of genomic DNA from bacteria. In Current Protocols in Molecular Biology. pp. 2.4.1-2.4.5. Edited by F. M. Ausubel, R. Brent, R. E. Kingston, D. D. Moore, J. G. Seidman, J. A. Smith \& K. Struhl. New York: Green Publishing and WileyInterscience. 